\title{
PENGARUH KONSENTRASI Na-ALGINAT DAN UKURAN BEADS TERHADAP STABILITAS BEADS DAN AKTIVITAS SEL Agrobacterium tumefaciens LSU20 IMMOBIL DALAM BIODESULFURISASI DIBENZOTHIOFENA
}

\author{
I Made Yoga Saputra ${ }^{1}$, Nyoman Semadi Antara ${ }^{2}$, Ida Bagus Wayan Gunam² \\ ${ }^{1}$ Mahasiswa Jurusan Teknologi Industri Pertanian, Fakultas Teknologi Pertanian, UNUD \\ ${ }^{2}$ Dosen Jurusan Teknologi Industri Pertanian, Fakultas Teknologi Pertanian, UNUD
}

E-mail: semadi.antara@unud.ac.id

\begin{abstract}
The purpose of this study was to determine the concentration and size of Na-alginate beads that have the highest degradation activity of dibenzothiophene. Biodesulfurization (BDS) of dibenzothiophene (DBT) was performed using $3 \mathrm{Na}$-alginate concentrations and 3 different beads sizes in the oil model system. Biodesulfurization was performed with incubation for 24 hours. The previous research showed that sodium alginate (Na-alginate) was an appropriate immobilizing agent compared to other immobilized materials. Na-alginate $4 \%$ show the activity of the degradation of the most good that is $66.33 \%$ (bead size $2 \mathrm{~mm}$ ), 62.99\% (bead size $3 \mathrm{~mm}$ ), $59.93 \%$ (bead size $4 \mathrm{~mm}$ ), for concentration of $3 \%$ Na-alginate showed $65.58 \%$ (bead size 2 $\mathrm{mm}$ ), $61.68 \%$ (bead size $3 \mathrm{~mm}$ ) and $60.43 \%$ (bead size $4 \mathrm{~mm}$ ), while concentration $5 \%$ showed the most low that is $64.86 \%$ (bead size $2 \mathrm{~mm}$ ), $61.01 \%$ (bead size $3 \mathrm{~mm}$ ), and $58.89 \%$ (bead size $4 \mathrm{~mm}$ ). The stability test showed Na-alginate $4 \%$ have the stability and durability of the bead stronger, the test showed Na-alginate can be used up to five repeat and still have degradation activity.
\end{abstract}

Key words: Biodesulfurization, Dibenzothiophene, Immobilized cells, Na-alginate.

\section{PENDAHULUAN}

Indonesia merupakan negara yang memilki kekayaan alam yang sangat luar biasa, salah satunya adalah energi minyak bumi. Energi merupakan salah satu sumber daya yang sangat penting dan sangat dibutuhkan pada era modern seperti sekarang ini. Berbagai aktivitas manusia saat ini sangat tergantung terhadap ketersediaan sumber daya energi (Hidayati, 2013). Minyak bumi walaupun persediaannya semakin menurun namun masih merupakan sumber energi utama dunia. Produksi dan konsumsi energi primer dunia menunjukkan peningkatan yang terusmenerus. Penggunaan energi meningkat dengan meningkatnya kebutuhan dan kemapanan. Penggunaan energi fosil terutama minyak bumi diakui mempunyai manfaat yang sangat luas namun mengandung senyawa beracun dan menimbulkan pencemaran lingkungan yang serius (Gunam et al., 2013).

Untuk menghilangkan senyawa sulfur yang berasal dari bahan bakar fosil dilakukan proses hidrodesulfurisasi. Proses hidrodesulfurisasi ini memerlukan biaya yang sangat mahal dan memerlukan energi yang tinggi. Selain itu beberapa senyawa sulfur organik kompleks sangat sulit dihilangkan dengan proses desulfurisasi (Park et al., 2003). Biodesulfurisasi salah satu metode yang bisa digunakan untuk menghilangkan senyawa sulfur aromatik dalam bahan bakar 
fosil. Biodesulfurisasi adalah suatu metode untuk menurunkan kandungan sulfur dengan memanfaatkan mikroorganisme. Biodesulfurisasi memiliki keuntungan utama dibandingkan dengan hidrodesulfurisasi yaitu proses ini tidak memerlukan kondisi reaksi yang tinggi seeperti misalnya suhu dan tekanan yang tinggi. Proses biodesulfurisasi ini dapat terjadi pada kondisi suhu dan tekanan normal. Selain keuntungan yang disebutkan di atas, biodesulfurisasi juga mempunyai keunggulan lain yakni biaya yang lebih hemat dan energi yang diperlukan lebih efisien (Sohrabi et al., 2012).

Biodesulfurisasi dapat dilakukan dengan growing cells, resting cells dan sel immobil. Proses biodesulfurisasi dengan growing cells dan resting cells sangat sulit dilakukan dan memerlukan jumlah sel yang banyak, serta sel sangat mudah terkontaminasi dan menurun viabilitasnya. Untuk mengatasi permasalahan ini proses biodesulfurisasi dapat dilakukan dengan sel immobil, karena imobilisasi sel dapat melindungi sel dari kondisi buruk lingkungan sekitar (suhu), proses separasi menjadi lebih mudah dan cepat, dan mempertahankan stabilitas sel. Berdasarkan penelitian sebelumnya telah dibuktikan bahwa bakteri Pseudomonas stutzeri UP-1 yang diimobilisasi dengan sodium alginat $4 \%$ dapat digunakan untuk mendesulfurisasi DBT secara efisien pada model minyak. Hasil menunjukkan bahwa sodium alginat merupakan bahan yang sangat sesuai karena memiliki tingkat kestabilan yang baik (Hou et al., 2005). Berdasarkan penelitian pendahuluan juga menunjukan bahwa Na-alginat dengan konsentrasi di bawah $4 \%$ memiliki viskositas yang rendah sehingga beads yang dihasilkan mudah hancur atau kurang kokoh dan bentuknya kurang seragam. Dengan demikian kemungkinan tidak dapat digunakan untuk mempertahankan viabilitas sel imobil selama penyimpanan. Sedangkan Na-alginat dengan konsentrasi lebih dari 8\%, memiliki viskositas yang tinggi sehingga menyebabkan kesulitan dalam pembentukan beads (Dewi, 2005). Pada penelitian yang telah dilakukan, konsentrasi Naalginat dan ukuran beads sudah diteliti pengaruhnya terhadap kemampuan immobil sel Agrobacterium tumefaciens LSU20 dalam mendegradasi sulfur dari dibenzothiophena. Pada penelitian ini dilakukan perbandingan konsentrasi bahan imobilisasi Na-alginat 3\%, 4\%, dan 5\% serta ukuran beads $2 \mathrm{~mm}, 3 \mathrm{~mm}$, dan $4 \mathrm{~mm}$ dengan tujuan untuk mendapatkan konsentrasi bahan dan ukuran beads dengan aktivitas tertinggi dalam biodesulfurisasi serta memiliki stabilitas yang baik.

\section{METODE PENELITIAN}

\section{Tempat dan Waktu Penelitian}

Penelitian ini telah dilakukan di Laboratorium Bioindustri dan Lingkungan Fakultas Teknologi Pertanian Universitas Udayana dan Laboratorium Forensik Polda Bali dari bulan November 2016 sampai Februari 2017.

\section{Bahan}

Strain bakteri Agrobacterium tumefaciens LSU20 diperoleh dari kultur stock Laboratorium Bioindustri dan Lingkungan Fakultas Teknologi Pertanian. Media untuk menumbuhkan dan media untuk pengujian biodesulfurisasi dilakukan dalam sistem 2 lapis, yaitu medium yang mengandung mineral dan bebas sulfur dan minyak bumi. Komposisi dari medium adalah sebagai berikut : $\mathrm{KH}_{2} \mathrm{PO}_{4}$ (Merck), $\mathrm{Na}_{2} \mathrm{HPO}_{4}$ (Merck), $\mathrm{NH}_{4} \mathrm{Cl}$ (Merck), $\mathrm{NaCl}$ (Applichem), $\mathrm{MgCl}_{2} 6 \mathrm{H}_{2} \mathrm{O}$ (Merck), $\mathrm{CaCl}_{2}$ (Merck), $\mathrm{FeCl}_{3}$ (Merck), $\mathrm{CuCl}_{2} \cdot 2 \mathrm{H}_{2} \mathrm{O}$ (Merck), $\mathrm{MnCl}_{2}$ (Merck), $4 \mathrm{H}_{2} \mathrm{O}$ (Merck), glukosa (Merck) dan senyawa sulfur organik yang telah terkonsentrasi 
(CA). Bahan lainnya: Dibenzothiophene (Aldrich), Tetradekana (Merck), Minyak bumi (crude oil), bahan untuk immobilisasi sel Na-Alginat (Fluka).

\section{Alat}

Peralatan yang digunakan adalah gas cromathography (Agilent Technologies 6890N), mass selective detector (Agilent Technologies 5973), kolom HP $5 \mathrm{MS}$ (60 m x 0,32 mm x 0,25 $\mu \mathrm{m}$; $\mathrm{J} \& \mathrm{~W}$ Scientific), $\mathrm{pH}$ meter (Schoot instrument), spektrofotometer (Thermo scientific), sentrifuge (K3 series), freezer, syringe, ice box, blue ice, timbangan analitik, tabung reaksi, bunsen, pipet mikro (Thermo scientific), incubator (Memmert), autoclave (Hirayama), laminar flow (Kojair), waterbath shaker (Memmert), magnetic stirrer (SSM 79-1 + Hot Plate), hot plate (Mini Portabel $500 \mathrm{~W} 220 \mathrm{~V}$ ), lemari pendingin (LG GN-B285SQBB), dan vortex (MX-FS, Continuous Operation).

\section{Pembuatan Media Petumbuhan}

Pembuatan media pertumbuhan MSSF (Mineral Salt Sulfur Free)-CA cair untuk media pertumbuhan mikroba yang mengandung senyawa sulfur aromatik terkonsentrasi (CA) yaitu dengan melarutkan 11,4 $\mathrm{g} \mathrm{KH}_{2} \mathrm{PO}_{4}, 28,85 \mathrm{~g} \mathrm{Na}_{2} \mathrm{HPO}_{4}, 10 \mathrm{~g} \mathrm{NH} 4 \mathrm{Cl}, 0,375 \mathrm{~g} \mathrm{NaCl}, 10,165 \mathrm{~g}$ $\mathrm{MgCl}_{2} \cdot 6 \mathrm{H}_{2} \mathrm{O}, 3,6746 \mathrm{~g} \mathrm{CaCl}_{2}, 1,351 \mathrm{~g} \mathrm{FeCl}, 0,0085 \mathrm{~g} \mathrm{CuCl}_{2} \cdot 2 \mathrm{H}_{2} \mathrm{O}, 0,0495 \mathrm{~g} \mathrm{MnCl}_{2} \cdot 4 \mathrm{H}_{2} \mathrm{O}, 1 \%$ glukosa, $0,1 \%$ senyawa sulfur aromatik terkonsentrasi (CA). Untuk pembuatan media uji degradasi dibenzothiophene MSSF-DBT cair sama dengan pembuatan media MSSF-CA cair, namun tidak menggunakan $\mathrm{CA}$ melainkan menggunakan dibenzothiophene yang dilarutkan dalam tetradekana (Gunam et al., 2013).

\section{Persiapan Kultur}

Kultur kerja dipersiapkan dengan menginokulasi strain bakteri yang telah diremajakan (dari kultur stok) sebanyak $0,5 \mathrm{ml}$ ke dalam tabung reaksi yang masing-masing berisi $5 \mathrm{ml}$ media MSSF-CA dan $5 \mu 1$ sulfur aromatik (CA), diinkubasi pada suhu ruang selama 96 jam dengan kecepatan putaran shaker $150 \mathrm{rpm}$. Setelah masa inkubasi, tabung reaksi yang berisi suspensi sel ditumbuhkan lagi pada media MSSF-CA dalam Erlenmeyer $250 \mathrm{ml}$ yang berisi $200 \mathrm{ml}$ media MSSF untuk dilakukan perbanyakan sel strain bakteri dan penambahan $1 \mathrm{ml} \mathrm{CA}$, diinkubasi pada suhu ruang selama 96 jam dan digojog dengan shaker pada kecepatan 150 rpm hingga didapat kultur kerja.

\section{Immobilisasi Menggunakan Na-Alginat}

Sebanyak 3\%, 4\%, \& 5\% Na-Alginat masing-masing dilarutkan pada $100 \mathrm{ml}$ aquades steril dan di aduk menggunakan magnetic stirrer sampai terlarut. Setelah itu disterilisasi pada suhu $121^{\circ} \mathrm{C}$ selama 15 menit. Setelah dingin, $6 \mathrm{ml}$ larutan $\mathrm{Na}$-alginat dicampurkan dengan $3 \mathrm{ml}$ suspensi sel yang telah ditentukan $\mathrm{OD}_{660}$. Kemudian di vortex untuk mencampur bahan dengan suspensi sel. Setelah itu campuran diinjeksikan pada larutan $\mathrm{CaCl}_{2} 4 \%$ (b/v) pada suhu ruang untuk pembentukan beads alginat dengan ukuran berbeda yaitu $2 \mathrm{~mm}, 3 \mathrm{~mm}$, dan $4 \mathrm{~mm}$, untuk mendapatkan ukuran beads tersebut sudah dilakukan pra penelitian sebelumnya yaitu dengan cara menyesuaikan lubang dari spuit yang akan digunakan. Sehingga mendapatkan ukuran beads yang diinginkan dan untuk mengeraskan butiran tersebut diperlukan waktu selama 6 jam pada suhu $4^{\circ} \mathrm{C}$. Sel imobil yang telah mengeras kemudian dicuci dengan menggunakan larutan garam dan kemudian disimpan pada freezer pada suhu $4^{\circ} \mathrm{C}$ hingga digunakan (Gunam et al., 2013).

\section{Biodesulfurisasi dengan Imobilisasi Sel}

Biodesulfurisasi dilakukan pada Erlenmeyer $100 \mathrm{ml}$ yang berisi 17,5 ml larutan garam ( $\mathrm{NaCl}$ 0,85\%) dan 1,25 ml tetradekana yang mengandung 200 ppm DBT dengan suhu inkubasi 
$37^{\circ} \mathrm{C}$ pada waterbath shaker dan digojog dengan kecepatan $150 \mathrm{rpm}$. Sebelum sel imobil digunakan terlebih dahulu dilakukan aktivasi selama 20 jam pada media larutan garam 0,85\% sebanyak $17,5 \mathrm{ml}$ dan $1 \mathrm{ml}$ glukosa dengan konsentrasi $1 \%$ sambil digojog dengan kecepatan $150 \mathrm{rpm}$ (Hou et al., 2005).

Setelah 20 jam bead dicuci dengan larutan garam 0,85\%, kemudian ditambahkan dengan 17,5 ml larutan garam $0,85 \%$ dan $1,25 \mathrm{ml}$ DBT $200 \mathrm{ppm}$ dalam tetradekana, dan diinkubasi pada waterbath shaker dan digojog dengan suhu $37^{\circ} \mathrm{C}$ dengan lama 24 jam sampai 72 jam untuk tiap sampel. Setelah waktu inkubasi berakhir bead dipisahkan dari media dengan memindahkan fase air dan fase minyak, sementara beads dilakukan pencucian dengan menggunakan larutan garam $0,85 \%$. Beads tersebut dapat digunakan kembali setelah aktivasi dengan menggunakan media larutan garam $0,85 \%$ yang mengandung glukosa. Fase air dilakukan analisis $\mathrm{pH}$ dan tingkat kekeruhan (OD), sedangkan fase minyaknya dianalisis residu DBT dalam tetradekana dengan GC-MS (Gunam et al., 2013).

\section{Pengujian Stabilitas Bahan Imobilisasi}

Pengujian stabilitas bahan imobilisasi dilakukan dengan cara melakukan biodesulfurisasi secara berulang - ulang dengan menggunakan bead yang sama dan dengan ukuran beads yang berbeda. Pengujian dilakukan dengan masa inkubasi 24 jam dan aktivasi 20 jam, setelah penggunaan selama 24 jam sel imobil diaktifkan kembali dengan larutan garam 0,85\% yang mengandung $1 \mathrm{ml}$ glukosa $1 \%$ selama 20 jam lalu sel imobil siap digunakan kembali. Kedua proses tersebut terus dilanjutkan hingga bead ada yang mengalami kerusakan.

\section{Variabel yang Diamati}

Variabel yang diamati meliputi tingkat kekeruhan $\left(\mathrm{OD}_{660}\right)$ dengan spektrofotometer dan derajat keasaman $(\mathrm{pH})$ menggunakan $\mathrm{pH}$ meter dari fase air, kemudian kadar residu DBT pada fase minyak dianalisis menggunakan GC-MS (Gas chromatography - Mass Spectrometry), serta pengujian stabilitas beads dengan tiga ukuran berbeda dari bahan immobilisasi Na-alginat dengan konsentrasi berbeda.

\section{HASIL DAN PEMBAHASAN}

Hasil analisis ragam (Tabel 1), menunjukkan bahwa perlakuan ukuran beads dan konsentrasi Na-alginat berpengaruh sangat nyata $(\mathrm{P}<0,01)$. Nilai rata-rata derajat keasaman $(\mathrm{pH})$ dapat dilihat pada Tabel 1.

Tabel 1. pH setelah inkubasi imobilisasi sel selama 24 jam pada DBT 200 ppm dalam tetradekana menggunakan bakteri Agrobacterium Tumefaciens pada bahan imobilisasi Na-alginat.

\begin{tabular}{cccc}
\hline \multirow{2}{*}{$\begin{array}{c}\text { Ukuran } \\
\text { Beads }(\mathrm{mm})\end{array}$} & \multicolumn{3}{c}{ Konsentrasi Na-alginat } \\
\cline { 2 - 5 } & $6,65 \pm 0,14$ a & $6,65 \pm 0,07 \mathrm{ab}$ & $6,80 \pm 0,07 \mathrm{ab}$ \\
2 & $6,30 \pm 0,07 \mathrm{ab}$ & $6,25 \pm 0,21 \mathrm{bc}$ & $6,55 \pm 0,28 \mathrm{bc}$ \\
3 & $6,00 \pm 0,21 \mathrm{bc}$ & $6,25 \pm 0,07 \mathrm{bc}$ & $6,25 \pm 0,00 \quad \mathrm{c}$ \\
\hline
\end{tabular}

Keterangan: Pengujian aktivitas biodesulfurisasi pada media $\mathrm{NaCl} 0,85 \%$ dan tetradekana. Diinkubasi pada waterbath shaker dengan suhu $37^{\circ} \mathrm{C}$ selama 24 jam dengan $\mathrm{pH}$ awal 7. 
Tabel 1 menunjukkan bahwa semakin kecil ukuran beads dan semakin besar konsentrasi bahan maka $\mathrm{pH}$ akan semakin rendah. Hal tersebut dikarenakan semakin banyak beads yang dihasilkan maka aktivitas desulfurisasi sulfur juga akan semakin tinggi. Penurunan $\mathrm{pH}$ mengindikasikan adanya aktivitas biodesulfurisasi dibenzotiofena yang disebabkan oleh mikroorganisme (Aditiawati et al., 2013). Semakin tinggi aktivitas biodesulfurisasinya maka akan menyebabkan penurunan $\mathrm{pH}$. Senyawa sulfur yang terdegradasi dalam bentuk $\mathrm{SO}_{3}{ }^{2-}$ dan $\mathrm{SO}_{4}{ }^{2-}$ tersebut akan larut pada fase air sehingga akan terbentuk asam yang dapat menyebabkan $\mathrm{pH}$ mengalami penurunan (Monticello, 2000). Semakin tinggi tingkat aktivitas mikroorganisme dalam mendegradasi dibenzotiofena juga dapat menyebabkan penurunan $\mathrm{pH}$. Senyawa sulfur yang terdegradasi tersebut akan larut pada fase air sehingga akan terbentuk asam yang dapat menyebabkan $\mathrm{pH}$ mengalami penurunan (Monticello, 2000).

Hasil analisis ragam (Tabel 2), menunjukkan bahwa perlakuan ukuran beads dan konsentrasi Na-alginat tidak berpengaruh sangat nyata $(\mathrm{P}>0,05)$. Nilai rata-rata derajat keasaman $(\mathrm{pH})$ dapat dilihat pada Tabel 2.

Tingkat kekeruhan menunjukkan semakin kecil konsentrasi Na-alginat maka tingkat kekeruhan cenderung meningkat (Tabel 2). Hal tersebut terjadi karena beads yang dihasilkan tidak terlalu keras sehingga pada pengujian mudah mengalami kebocoran pada beads. Selain dari adanya aktivitas dari mikroorganisme, peningkatan kekeruhan juga disebabkan karena adanya kebocoran dari bahan imobilisasi sehingga sel yang diperangkap di dalam bahan keluar dan membuat fase air menjadi keruh (Naito et al., 2001).

Tabel 2. Perubahan tingkat kekeruhan pada biodesulfurisasi DBT menggunakan sel imobil Agrobacterium tumefaciens LSU20 dengan model minyak tetradekana pada $\lambda=660$

\begin{tabular}{cccc} 
Ukuran & \multicolumn{3}{c}{ Konsentrasi Na-alginat } \\
\cline { 2 - 4 } Beads $(\mathrm{mm})$ & $3 \%$ & $4 \%$ & $5 \%$ \\
\hline 2 & $0,091 \pm 0,01 \mathrm{a}$ & $0,082 \pm 0,00 \mathrm{a}$ & $0,081 \pm 0,00 \mathrm{a}$ \\
3 & $0,105 \pm 0,02 \mathrm{a}$ & $0,083 \pm 0,00 \mathrm{a}$ & $0,083 \pm 0,00 \mathrm{a}$ \\
4 & $0,113 \pm 0,03 \mathrm{a}$ & $0,096 \pm 0,01 \mathrm{a}$ & $0,093 \pm 0,01 \mathrm{a}$ \\
\hline
\end{tabular}

Keterangan : Pengujian aktivitas biodesulfurisasi pada media $\mathrm{NaCl} 0,85 \%$ dan tetradekana. Diinkubasi pada waterbath shaker dengan suhu $37^{\circ} \mathrm{C}$ selama 24 jam dengan $\mathrm{pH}$ awal 7.

Pada penelitian yang sudah dilakukan, Na-alginat dengan konsentrasi 5\% memiliki ketahanan beads yang yang sangat bagus dan tidak mudah hancur, namun sangat sulit untuk dihomogenisasi dan dalam medegradasi dibenzotiofena agak kurang. Hal tersebut menunjukkan sedikitnya kebocoran dalam beads yang mengakibatkan peningkatan OD tidak terlalu tinggi. Sebaliknya Na-alginat dengan konsentrasi 3\% mengalami peningkatan OD yang cukup tinggi, hal tersebut disebabkan karena ketahanan beads yang kurang bagus dan sangat mudah hancur. Na-alginat dengan konsentrasi $4 \%$ juga menunjukan ketahanan beads yang cukup bagus, konsentrasi $4 \%$ meiliki tingkat degradasi yang paling tingggi. Na-alginat dengan konsentrasi $4 \%$ juga lebih mudah untuk dihomogenisasi (Sitepu, 2011).

Hasil penelitian menunjukkan bahwa residu DBT dari Na-alginat dengan konsentrasi $4 \%$ memiliki residu DBT yang terendah, dimana semakin rendah residu DBT yang dihasilkan maka aktivitas dari sampel menunjukkan hasil yang lebih bagus. Pada Tabel 3 dapat dilihat bahwa DBT yang awalnya 200 ppm menjadi berkurang, residu atau sisa DBT dari Na-alginat 3\% 
sebesar 68,85 ppm, 76,64 ppm, dan 79,15 ppm dengan ukuran beads yang berbeda yaitu $2 \mathrm{~mm}, 3$ $\mathrm{mm}$, dan $4 \mathrm{~mm}$. Na-alginat 5\% sebesar 70,28 ppm, 77,99 ppm, dan 82,23 ppm dengan ukuran beads yang berbeda yaitu $2 \mathrm{~mm}, 3 \mathrm{~mm}$, dan $4 \mathrm{~mm}$. Sedangkan Na-alginat 4\% menunjukan hasil yang paling rendah yaitu $67,33 \mathrm{ppm}, 74,03 \mathrm{ppm}$, dan 80,14 ppm dengan ukuran beads yang berbeda yaitu $2 \mathrm{~mm}, 3 \mathrm{~mm}$, dan $4 \mathrm{~mm}$.

Tabel 3. Residu DBT (ppm) pada biodesulfurisasi DBT menggunakan sel imobil Agrobacterium tumefaciens LSU20 dengan model minyak tetradekana.

\begin{tabular}{|c|c|c|c|}
\hline \multirow{2}{*}{$\begin{array}{c}\text { Ukuran } \\
\text { Beads }(\mathrm{mm})\end{array}$} & \multicolumn{3}{|c|}{ Konsentrasi Na-alginat } \\
\hline & $3 \%$ & $4 \%$ & $5 \%$ \\
\hline 2 & $68,85 \pm 1,47 \mathrm{~cd}$ & $67,33 \pm 0,33 \mathrm{~d}$ & $70,28 \pm 0,72 \mathrm{~cd}$ \\
\hline 3 & $76,64 \pm 1,56 \mathrm{ab}$ & $74,03 \pm 1,10 \mathrm{bc}$ & $77,99 \pm 0,78 \mathrm{ab}$ \\
\hline 4 & $79,15 \pm 2,27 \mathrm{ab}$ & $80,14 \pm 1,80 \mathrm{a}$ & $82,23 \pm 0,72 \mathrm{a}$ \\
\hline
\end{tabular}

Keterangan : Pengujian aktivitas biodesulfurisasi pada media $\mathrm{NaCl} 0,85 \%$ dan tetradekana. Diinkubasi pada waterbath shaker dengan suhu $37^{\circ} \mathrm{C}$ selama 24 jam dengan $\mathrm{pH}$ awal 7.

Tingkat degradasi juga menunjukkan hal yang sama yaitu Na-alginat $4 \%$ memiliki aktivitas tertinggi dalam mendegradasi DBT. Pada Tabel 4 terlihat tingkat degradasi Na-alginat 4\% mencapai 66,33\%, 62,99\%, dan 59,93\% dengan ukuran beads yang berbeda yaitu 2 mm, 3 $\mathrm{mm}$, dan $4 \mathrm{~mm}$ dan lama inkubasi selama24 jam. Sedangkan Na-alginat 3\% mendegradasi DBT sedikit lebih rendah dibandingkan Na-alginat 4\%, yaitu $65,58 \%, 61,68 \%$, dan 60,43\% dengan waktu inkubasi yang sama yaitu 24 jam. Na-alginat 5\% menunjukkan hasil degradasi paling rendah diantara 2 konsentrasi lainnya yaitu 64,86\%, 61,01\%, dan 58,89\% dengan waktu inkubasi 24 jam. Menurut penelitian pendahulunya free cell digunakan sebagai pembanding. Hasil dari biodesulfurisasi menggunakan free cell tersebut ternyata memang lebih kecil, yaitu 52,30\%, $54,81 \%$, dan 55,95\%. Hasil tersebut membuktikan bahwa dengan imobilisasi sel dapat menjaga atau melindungi sel dari efek fisiokimia seperti temperatur, pelarut, dan $\mathrm{pH}$ (Kourkoutas et al., 2004). Karena sel yang diperangkap dalam bahan imobilisasi sudah terlindungi maka dapat meningkatkan aktivitas dan stabilitasnya dalam mendegradasi DBT menjadi lebih optimal (Tang et al., 2012).

Tabel 4. Tingkat degradasi DBT (\%) pada biodesulfurisasi DBT menggunakan sel imobil Agrobacterium tumefaciens LSU20 dengan model minyak tetradekana.






\section{Stabilitas Bahan Imobilisasi Na-Alginat}

Berdasarkan dari hasil biodesulfurisasi dengan waktu inkubasi 24 jam didapatkan hasil bahwa bahan imobilisasi Na-alginat dengan konsentrasi bahan $4 \%$ dan dengan ukuran beads yaitu $2 \mathrm{~mm}$ mendapatkan hasil degradasi tertinggi dibandingkan dengan konsentrasi Na-alginat yang lainnya. Setelah didapatkan hasil tersebut kemudian Na-alginat dengan konsentrasi yang berbeda kembali diuji untuk tingkat stabilitas dan ketahanannya jika digunakan berulang - ulang.

Tabel 5. Biodesulfurisasi berulang - ulang dengan menggunakan sel imobil dari Na-alginat

\begin{tabular}{|c|c|c|c|}
\hline \multirow{2}{*}{$\begin{array}{c}\text { Ukuran } \\
\text { Beads (mm) }\end{array}$} & \multicolumn{3}{|c|}{ Konsentrasi Na-Alginat } \\
\hline & $3 \%$ & $4 \%$ & $5 \%$ \\
\hline 2 & $65,58 \pm 0,52 \quad a$ & $66,28 \pm 0,15 \quad a$ & $64,81 \pm 0,27 \quad a$ \\
\hline 3 & $61,87 \pm 0,64 \quad b c$ & $62,99 \pm 0,39 \quad b$ & $61,10 \pm 0,32 \mathrm{~cd}$ \\
\hline 4 & $60,33 \pm 0,82$ cde & $60,09 \pm 0,69 \mathrm{de}$ & $59,17 \pm 0,55$ e \\
\hline
\end{tabular}

Keterangan : Pengujian aktivitas biodesulfurisasi pada media Nacl 0,85\% dan tetradekana. Diinkubasi dengan waterbath shaker pada suhu $37^{\circ} \mathrm{C}$ selama 24-72 jam dengan $\mathrm{pH}$ awal 7.

Na-alginat memiliki stabilitas dan ketahanan beads yang sangat baik, hal tersebut terlihat dari kemampuan Na-alginat mampu bertahan hingga ulangan ke-3. Na-alginat dengan konsentrasi 5\% memiliki ketahanan beads yang paling bagus, hal tersebut terlihat dari keutuhan beads setelah pengujian ulangan ke-3. Namun Na-alginat dengan konsentrasi $4 \%$ tidak memperlihatkan perbedaan yang cukup jauh dari Na-alginat konsentrasi 5\%. Sedangkan Naalginat dengan konsentrasi 3\% memperlihatkan ketahanan beads yang tidak terlalu bagus, hal itu terlihat dari lemahnya ketahanan beads pada saat dilakukan pengujian berulang-ulang.

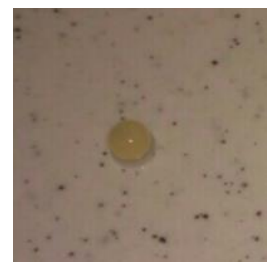

( a )

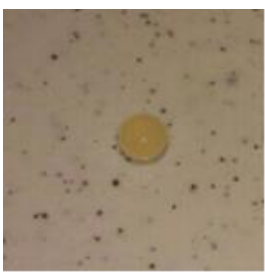

( b )

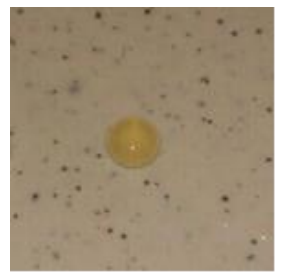

( c)

Gambar 1. Ukuran bead Na-alginat dengan tiga ukuran berbeda. (a) bead $2 \mathrm{~mm}$; (b) bead $3 \mathrm{~mm}$; (c) bead $4 \mathrm{~mm}$.

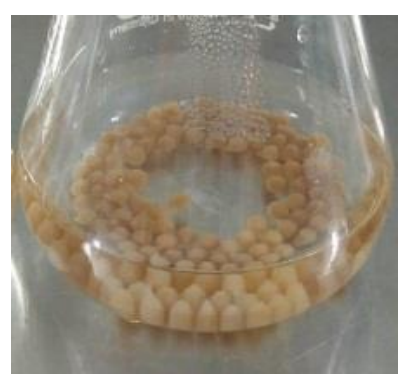

(a)

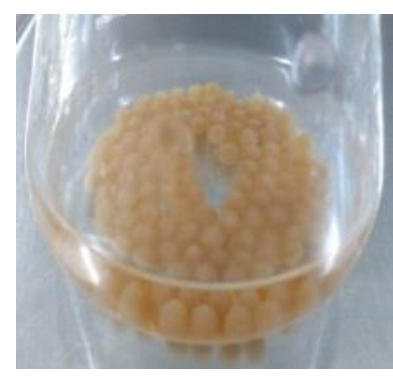

(b)

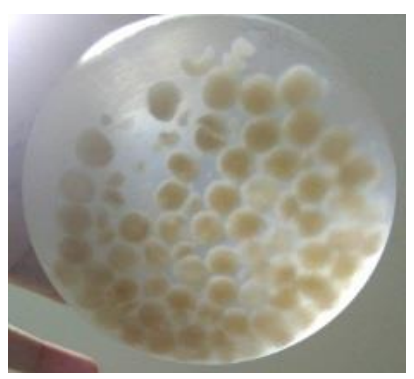

(c) 
Gambar 2. Bentuk bead Na-alginat setelah dilakukan uji stabilitas biodesulfurisasi pada DBT 200 ppm dalam model minyak tetradekana. (a) Na-alginat 5\%; (b) Na-alginat 4\%; (c) Na-alginat $3 \%$.

Na-alginat dengan konsentrasi 5\% memiliki ketahanan beads yang paling bagus, akan tetapi dalam kemampuan mendegradasi DBT masih kurang dibandingkan dengan Na-alginat dengan konsentrasi 4\% bahkan dengan Na-alginat 3\% sekalipun. Hal tersebut terlihat dari hasil pengujian berulang-ulang yang dilakukan pada ketiga konsentrasi bahan yang sudah ditampilkan pada Tabel 5 di atas.

\section{KESIMPULAN DAN SARAN}

\section{Kesimpulan}

Dari hasil penelitian yang sudah dilakukan diperoleh konsentrasi bahan dan ukuran beads terbaik, yaitu Na-alginat dengan konsentrasi 4\% dan ukuran beads $2 \mathrm{~mm}$ atau dengan ukuran beads terkecil. Hasil pengujian yang dilakukan dapat diketahui bahwa konsentrasi Na-alginat $4 \%$ menunjukan hasil degradasi DBT tertinggi dibandingkan dengan dua konsentrasi lainnya, yaitu $66,33 \%$ pada ukuran beads $2 \mathrm{~mm}$, 62,99\% pada ukuran beads $3 \mathrm{~mm}$, dan $59,93 \%$ pada ukuran beads $4 \mathrm{~mm}$. Dari hasil diatas juga dapat disimpulkan bahwa Na-alginat dengan konsentrasi $4 \%$ dan dengan ukuran beads terkecil $(2 \mathrm{~mm})$ memperlihatkan hasil paling bagus dan memiliki stabilitas dan ketahanan beads yang baik.

\section{Saran}

Dalam peremajaan dan perbanyakan kultur perlu ketelitian sehingga nantinya sel yang terkumpul dapat mencukupi untuk penelitian immbolisasi sel ini. Karena pada penelitian ini menggunakan OD yang cukup tinggi, sehingga jumlah sel sangat penting untuk mendapat OD yang tinggi tersebut. Penelitian lebih lanjut juga diperlukan untuk mengetahui aktivitas desulfurisasinya pada minyak bumi.

\section{DAFTAR PUSTAKA}

Aditiawati, P., Akhmaloka, D.I. Astuti, Sugilubin, and M.R. Pikoli. 2013. Biodesulfurization of subbituminous coal by mixed culture bacteria isolated from coal mine soil of south sumatera. Biotechnology 12 (1):46-53.

Gunam, I.B.W., Y. Yaku, M. Hirano, K. Yamamura, F. Tomita, T. Sone, and K. Asano. 2006. Biodesulfurization of slkylated forms of dibenzothiophene and benzothiophene by Sphingomonas subartica T7b. Journal of Bioscience and Bioengineering. 101(4):322-327.

Gunam, I.B.W., K. Yamamura, I.N. Sujaya, N.S. Antara, W.R. Aryanta, M. Tanaka, F. Tomita, T. Sone, and K. Asano. 2013. Biodesulfurization of dibenzothiphene and its derivates using resting and immobilized cells of Sphingomonas subartica T7b. J. Microbiol. Biotechnol. 23(4):473- 482 . 
Gunam, I.B.W., M. Iqbal, I.W. Arnata, N.S. Antara, A.A.M. Dewi Anggreni, Y. Setiyo, I.B.P. Gunadnya. 2016. Biodesulfurization of dibenzothiophene by a newly isolated Agrobacterium tumefaciens LSU20. Applied Mechanics and Materials. 855:143-149.

Hidayati, N. 2013. Studi Konversi Batubara Menjadi Fraksi Bahan Bakar Cair Melalui Pirolisis dan Hidrorengkah Katalitik Dengan CoMo/ZAA Sebagai Katalis. Skripsi. Jurusan Kimia, Fakultas Matematika dan Ilmu Pengetahuan Alam. Universitas Gajah Mada, Yogyakarta.

Hou,Y., Y. Kong, J. Yang, J. Zhang, D. Shi, and W. Xin. 2005. Biodesulfurization of dibenzothiophene by immobilized cells of Pseudomonas stutzeri UP-1. Fuel 84:1975-1979.

Kourkoutas, Y., A. Bekatorou, I, Banat. 2004. Immobilization technologies and support materials suitable in alcohol beverages production: a review. Food Microbiology. 21(4):377-397.

Monticello, D.J. 2000. Biodesulfurization and the upgrading of petroleum distillates. current opinion in biotechnology. 11:540 - 546 .

Naito, M., T. Kawamoto, K. Fujino, M. Kobayashi, K. Maruhashi, A. Tanaka. 2001. Long-term repeated biodesulfurization by immobilized Rhodococcus erythropolis KA2-5-1 cells. J. Microbiol. Biotechnol. 55:374-378.

Park, S.J., I.S. Lee, Y.K. Chang, and S.Y. Lee. 2003. Desulfurization of dibenzothiphene and diesel oil by metabolically engineered Eschericia coli. J. Microbiol. Biotechnol. 13(4):578 -583 .

Sitepu, A. 2011. Biodesulfurisasi Dibenzothiophene dalam Tetradecane Menggunakan Isolat KWN5 yang Terimmobilisasi. Skripsi. Jurusan Teknologi Industri Pertanian, Fakultas Teknologi Pertanian. Universitas Udayana. Bali.

Sohrabi, M., H. Kamyab, N. Janalizadeh, and F.Z. Huyop. 2012. Bacterial desulfurization of organic sulfur compound exist in fossil fuels. Journal of Pure and Applied Microbiology. $6(2): 717-729$.

Tang, H., Q. Li, W. Zelong, D. Yan, and J. Xing. 2012. Simultaneous removal of thiophene and dibenzothiophene by immobilized Pseudomonas delafieldii R-8 cells. Chinese Journal of Chemical Engineering. 20(1):47-51. 